\title{
Human Enteric Pathogens in Eight Rivers Used as Rural Household Drinking Water Sources in the Northern Region of South Africa
}

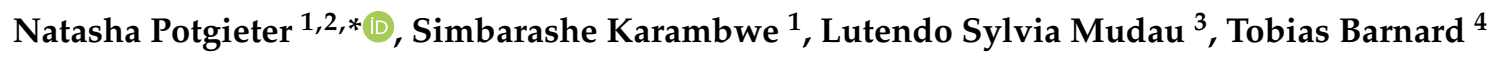 \\ and Afsatou Traore ${ }^{1}$ D \\ 1 Microbiology Department, University of Venda, Private Bag X5050, Thohoyandou 0950, South Africa; \\ karambwesim@gmail.com (S.K.); Afsatou.traore@univen.ac.za (A.T.) \\ 2 Dean, School of Mathematical and Natural Sciences, University of Venda, Private Bag X5050, \\ Thohoyandou 0950, South Africa \\ 3 Department of Environmental Health, Tshwane University of Technology, Private Bag X680, \\ Pretoria 0001, South Africa; MudauLS@tut.ac.za \\ 4 Water \& Health Research Center, University of Johannesburg, PO Box 524, 2006 Auckland Park, \\ Johannesburg 2094, South Africa; tgbarnard@uj.ac.za \\ * Correspondence: natasha.potgieter@univen.ac.za
}

Received: 1 February 2020; Accepted: 9 March 2020; Published: 20 March 2020

\begin{abstract}
People living in rural areas still rely on the use of environmental water that is contaminated by human and animal activities. This study assessed the occurrence of human enteric pathogens in rivers that are used by rural communities Vhembe District of South Africa as a source of drinking water covering two seasons (winter and summer) over a one-year period. Water quality was assessed using physico characteristics and indicator organisms (total coliforms, E. coli, Clostridium perfringens). Pathogens tested included bacteria (Pathogenic E. coli, Salmonella-, Shigella- and Vibrio spp.), protozoa (Cryptosporidium- and Giardia spp.), and enteric viruses (Rota-, Noro-, Entero-, and Adenoviruses) while using published molecular protocols. The results showed that the indicator bacteria counts exceeded South African drinking water quality guideline limits and pathogenic E. coli was detected in the samples. No Shigella spp. were isolated, while Vibrio spp. and Salmonella spp. were present; parasites were detected in four rivers and Enteric viruses were predominantly detected in the winter season. The results indicated the poor condition of water and the potential health risks to consumers highlighting the need for implementing river catchment management strategies for continued sustainability in these rivers.
\end{abstract}

Keywords: enteric pathogens; diarrhoea; river water; rural communities; Vhembe District; water quality

\section{Introduction}

Various rivers in South Africa have been shown to be highly polluted due to impacts from water and land use practices in their catchments [1-5]. Very few studies and reports on waterborne diarrhoea in the rural communities in the Vhembe region (Limpopo province, South Africa) are available, and it is highly possible that some diarrhoea cases go unreported. Settlements in rural and peri-urban areas are sparsely distributed due to the rough terrain, and this hinders the capacity to provide a centralized drinking water system [6]. Most of the communities in rural areas in the Limpopo province of South Africa have limited access to municipal water and might resort to the use of nearby surface water sources for their daily subsistence [5,7].

Rural populations obtain water on an individual or household basis from the closest surface and ground water sources where the microbial quality is often unknown [8]. In the Vhembe District, 
many of the communities rely on river water sources, which are devoid of treatment, and water collected from boreholes for their domestic water needs. It has been reported that most of the river water in this area is of poor microbiological quality and unsafe for consumption $[5,9,10]$. In addition, households' resort to the storing of water in different containers due to the distance of the sources and the infrequent availability of water [11]. These practices expose residents to waterborne pathogens that cause enteric diseases, such as diarrhoea, and have been reported as being responsible for the most health-related water quality problems [12]. Regardless of health education efforts, communities in the northern region of South Africa continue using unprotected sources without any form of treatment, as they perceive it as unimportant [13].

The use of untreated water for drinking and other domestic purposes, such as food preparation, washing clothes, and bathing, might be harmful to the communities [7]. Several human infections are waterborne and diseases, such as diarrhoea, are affected by fluctuations in weather and climate. In the Limpopo province, winters are usually dry, and the summers are hot with seasonal rains [5]. Dry conditions are associated with diarrhoea in children under five years of age, mainly due to the increase water storage in poor households, which leads to a higher risk of water contamination [14].

The prevention of water pollution requires effective and continuous monitoring of physical, chemical, and microbiological parameters to ascertain the possible risks that are associated with water from a particular source [15]. Continuous epidemiological and prevalence assessment of diarrhoeagenic pathogens in different water sources in rural and the majority of peri-urban communities will provide information to health statisticians on the prevalent strains circulating in these communities and these data will add to the knowledge of treatment effectiveness and intervention strategies. The objective of this study was to assess the prevalence of human enteric pathogens (bacteria, viruses, and parasites) in river water sources that are used for domestic purposes in rural communities of the Limpopo Province of South Africa.

\section{Materials and Methods}

\subsection{Study Site}

This study focused on eight rivers in the Vhembe District based on their proximity to human communities that use them as a source of drinking water. The water samples were collected from 10 sampling sites in three different Districts within the Limpopo Province: In the Thulamela Municipality (Tshinane river, Mutshundudi river, Sambandou river, Luvuvhu river: Mutoti site, Luvuvhu river: Mhinga site, Dzindi river, Madadzhe river); in the Mutale Municipality (Mutale river); and, in the Makhado Municipality (Nzhelele river, Luvuvhu river: Tshino site).

\subsection{Sample Collection}

The samples were collected twice [once in the winter season (June, July) and once in the summer season (October, November)] in a one-year period during 2016. The samples were collected at the abstraction points used by communities in each river site. Clean sterile $10 \mathrm{~L}$ plastic drums were used to collect water samples for viral and parasite analysis (one each) and $2 \times 500 \mathrm{~mL}$ sterile plastic containers for bacterial analysis were used to collect water samples for indicator assessments at each site. Observations that were related to human activities were noted during water collection. All of the water samples were stored on ice on route to the laboratories for analysis within $4 \mathrm{~h}$. Temperature (Temp), electrical conductivity (EC), Total Dissolved Solids (TDS), dissolved oxygen (DO), and pH were measured in situ while using a Bante 900P portable multimeter (Bante Instruments; Shanghai, China).

\subsection{Indicator Bacteria Detection}

The Colilert Quanti-Tray ${ }^{\circledR} / 2000$ most probable number (MPN) method (IDEXX; Westbrook, ME; USA) was used according to the manufacturer's instructions to determine the presence of $E$. coli and total coliforms. No dilutions were performed and, in cases, were the upper limit of the test 
was reached ( $>2419.6 \mathrm{MPN} / 100 \mathrm{~mL}$ ) the data are reported as $>2420 \mathrm{MPN} / 100 \mathrm{~mL}$. The appropriate Quanti-Cult reference strains bacterial controls (E. coli, Klebsiella pneumoniae, and Pseudomonas aeruginosa) and distilled water (negative control) was used as controls in all the assessments.

The membrane filtration method followed by culturing of the filters on $\mathrm{m}-\mathrm{CP}$ agar plates were used to assess the presence of Clostridium perfringens in the river waters [16]. Briefly, $100 \mathrm{~mL}$ of water samples were heated at $60^{\circ} \mathrm{C}$ for $20 \mathrm{~min}$. in sterile glass conical flasks, as described by Mueller-Spitz et al. [17]. After cooling, the water was filtered using $0.45 \mu \mathrm{m}$ pore size, $47 \mathrm{~mm}$ diameter cellulose acetate filters. (Merck, Kenilworth, NJ, USA). In this study, $3 \mathrm{~mL}, 10 \mathrm{~mL}$, and $30 \mathrm{~mL}$ volumes were filtered [18]. The filters were transferred to sterile m-CP agar plates (Oxoid CM0992, pH 7.6) and anaerobically incubated at $42^{\circ} \mathrm{C}$ for $24 \mathrm{~h}$ [19] in a jar containing AnaeroGen ${ }^{\mathrm{TM}}$ sachets (Oxoid, Hampshire, UK). Yellow colonies that turned pink on exposure to ammonium hydroxide fumes were considered presumptive C. perfringens.

\subsection{Pathogenic Bacteria Identification}

The isolation of $V$. cholerae from water samples was performed according to Choopun et al. [20]. A volume of $100 \mathrm{~mL}$ of each sample was filtered through a $0.45 \mu \mathrm{m}$ pore size $47 \mathrm{~mm}$ cellulose acetate filter (Sartorius Biolab Products, Lasec, Cape Town, South Africa). The filters were enriched in $100 \mathrm{~mL}$ alkaline peptone water (Sigma-Aldrich, St Louis MO, USA, $2 \% \mathrm{NaCl}$ ) at $30^{\circ} \mathrm{C}$ for $24 \mathrm{~h}$. A volume of $10 \mu \mathrm{L}$ of the enriched samples was streaked onto TCBS agar plates ( $\mathrm{pH}$ 8.6, Davies Diagnostics Pty, Limited, Randburg, South Africa). The plates were incubated at $37^{\circ} \mathrm{C}$ for $24 \mathrm{~h}$. All the yellow and green-yellow colonies were considered as presumptive positive $V$. cholerae.

The isolation of Salmonella spp. and Shigella spp. from water samples $(100 \mathrm{~mL})$ was performed while using the membrane filtration technique with $0.45 \mu \mathrm{m}, 47 \mathrm{~mm}$ filters (Sartorius Biolab Products, Lasec). The membrane filters were submerged into $100 \mathrm{~mL}$ buffered peptone water (Oxoid CM0509, $\mathrm{pH}$ 7.2). The flasks were shaken by hand for $5 \mathrm{~min}$. to mix the trapped bacteria on the filter pads with the pre-enrichment broth and then incubated at $30^{\circ} \mathrm{C}$ and $37^{\circ} \mathrm{C}$ for $24 \mathrm{~h}$, respectively. A successive selective enrichment step in Rappaport-Vassiliadis Soya Peptone Broth (RVS) (Oxoid CM0866, pH 5.2), Nutrient broth (Sigma-Aldrich pH 7.5) and Selenite cysteine broth (SCB) (Difco, BD Product pH 7.0), accompanied by incubation at $42{ }^{\circ} \mathrm{C}$ for $48 \mathrm{~h}$ was performed. Thereafter, a loopful of the enriched samples was streaked on selective media; S-S agar (Difco, BD Product $\mathrm{pH}$ 7.0), a selective media for Salmonella and Shigella spp., and the plates were incubated at $37^{\circ} \mathrm{C}$ for $24 \mathrm{~h}$.

All of the presumptive colonies for Vibrio, Salmonella, and Shigella were sub-cultured onto Nutrient agar and then subjected to the oxidase test (Oxidase strips, Sigma-Aldrich), API 20E test (bioMerieux Product, Quantum Biotech) and Gram stained according to the protocol that was described by Prescott [21] and Wiley et al. [22]. The isolates were preserved in Nutrient broth and then stored at $-20^{\circ} \mathrm{C}$ until further analysis.

The DNA extraction and mPCR protocol published by Mieta et al. [23] was used for confirmation of Vibrio-, Salmonella-, and Shigella species from the presumptive isolates. The DNA extraction and mPCR protocols that were published by Omar and Barnard [24] was used for the identification of pathogenic E. coli strains from the E. coli positive wells on the Quanti-Tray ${ }^{\circledR} / 2000$. The Biorad Mycycler Thermal cycler was used for all of the PCR reactions in a total volume of $20 \mu \mathrm{L}$. All of the colonies that could not be identified by the PCR protocols were then identified using the API20E kit, according to the manufacturer's instructions (bioMerieux, Marcy I'Etoile, France).

\subsection{Pathogenic Protozoa Detection}

The samples were analyzed at a South African National Standards (SANS) accredited laboratory (Rand Water, Gauteng, South Africa), in compliance with ISO/IEC 17025. Method 1623.1, as described by the United States Environmental Protection Agency (USEPA) [25]. Briefly, each 10 L water sample was separately filtered using the PALL system with Envirochek capsules (Port Washington, NY, USA). The trapped oocysts and cysts together with extraneous materials were eluted while using $10 \%$ Tween 
80 and then collected into a $50 \mathrm{~mL}$ centrifuge tube. The eluate was centrifuged at $1500 \times g$ to pellet the oocysts and cysts. The supernatant was aspirated. The oocysts and cysts were then separated from the extraneous materials while using the immunomagnetic separation technique employing paramagnetic beads (Dynabeads ${ }^{\circledR}$ GC-Combo, Thermo Fisher Scientific, Gauteng, South Africa) that were conjugated to anti-Cryptosporidium and anti-Giardia antibodies. In the presence of oocysts or cysts, a paramagnetic complex is formed, which is then attracted by a magnet separating the oocysts/cysts from the extraneous materials. The beads were detached from the oocysts/cysts which were stained with fluorescently labelled monoclonal antibodies and 4'6-diamidino-2-phenyl indole (DAPI) on slides. The observation of the stained slides was done under fluorescence DIC microscopy (BW Optics, Nanjing, China) to assess the presence of oocysts/cysts.

\subsection{Pathogenic Viral Detection}

Viruses were recovered from each of the $10 \mathrm{~L}$ surface water samples while using the glass wool adsorption-elution primary recovery and secondary concentration method. Briefly, the modified method that was described by Mans et al. [26] used $15 \mathrm{~g}$ of glass wool per column and a steel gauze grid (pore size $=1 \mathrm{~mm}^{2}, 30 \mathrm{~mm}$ diameter) inserted between each of the three $5 \mathrm{~g}$ portions of the glass wool. Positively charged glass wool columns were used to capture the viruses that are generally negatively charged [27]. The negatively charged viruses, which had adsorbed to the glass wool, were eluted with $100 \mathrm{~mL}$ of sterile glycine-beef-extract buffer of $\mathrm{pH} 9.5(0.3754 \% w / v$ glycine, $0.5 \%$ beef extract), which reverses the ionic charges of the viruses and releases them from glass wool. The $\mathrm{pH}$ of the eluate was adjusted to neutral with $1 \mathrm{M} \mathrm{HCl}$. In the secondary concentration step, the $100 \mathrm{~mL}$ eluate was concentrated to a final volume of $20 \mathrm{~mL}$ in sterile phosphate buffered saline (pH 7.4, Sigma-Aldrich Co., USA) by polyethylene glycol (PEG)/sodium chloride ( $\mathrm{NaCl}$ ) precipitation, as described by Minor [28] and Vilagines et al. [29]. The recovered concentrate was stored at $-20^{\circ} \mathrm{C}$ until further processing. One millilitre each of all of the recovered viral concentrates were seeded with $10 \mu \mathrm{L}$ of Mengovirus ( $5 \times 10^{5}$ copies) as an extraction control and the nucleic acids were extracted while using the NucliSENS ${ }^{\circledR}$ EasyMAG ${ }^{\circledR}$ instrument (BioMerieux, Marcy I'Etoile, France), according to the manufacturer's instructions. The extracted nucleic acids were eluted into $100 \mu \mathrm{L}$, aliquoted in smaller volumes, and stored at $-70^{\circ} \mathrm{C}$. Mengovirus were detected for all the reactions.

Virus amplification were performed on three cell lines, which included the PLC/PRF/5 human hepatoma cell line (European Collection of Cell Cultures (ECACC) 85061113, Salisbury, UK) [30]; the BGM African Green monkey kidney cell line (ECACC 90092601) [31]; and, the Vero African Green monkey kidney cell line (ECACC84113001). All of the cells lines were propagated, maintained, and infected using standard cell culture procedures, as previously described $[26,32,33]$. The harvested cell culture suspensions $(500 \mu \mathrm{L})$ were subjected to three cycles of freezing and thawing prior to nucleic acid extraction from $200 \mu \mathrm{L}$ of harvested cell culture extracts while using the NucliSENS ${ }^{\circledR}$ EasyMAG $^{\circledR}$ instrument (BioMerieux), according to the manufacturer's instructions. The extracted nucleic acids were eluted in $50 \mu \mathrm{L}$, aliquoted in smaller volumes, and then stored at $-70{ }^{\circ} \mathrm{C}$. For the integrated cell culture-molecular based assay, Enteroviruses were detected with a one-step real-time RT-PCR assay using the Quantitect Probe RT-PCR Kit (Qiagen, Hilden, Germany) and primers and a hydrolysis probe, as previously described [34], and the adenoviruses using primers and probes, as described by Heim et al. [35] in the TaqMan ${ }^{\circledR}$ Environmental Master Mix 2.0 kit.

Commercial real-time RT-PCR assays for each enteric virus were used for the direct detection of selected human pathogenic enteric viruses in the recovered virus concentrate.

- $\quad$ Adenoviruses: a $r t$ PCR, using TaqMan technology and primers and probes, as described by Heim et al. [35], was optimized and used for the analysis of all the samples. The molecular amplification and $r t$ PCR detection of AdVs was done while using the TaqMan ${ }^{\circledR}$ Environmental Master Mix 2.0 (Applied Biosystems, Foster City, CA, USA).

- $\quad$ Astroviruses: a commercial $r$ RT-PCR assay (KASV: ceeramTools ${ }^{\circledR}$, CEERAM S.A.S., La Chapelle Sur Erdre, France), using TaqMan technology was used for the analysis of all the samples. 
- Enteroviruses: the commercial $r$ RT-PCR assay (KENV: ceeramTools $\left.{ }^{\circledR}\right)$, using TaqMan technology using the primers and probes, as described by Fuhrman et al. [34], was used for the analysis of all samples.

- Hepatitis A virus (HAV): a commercial $r t$ RT-PCR assay (KHAV: ceeramTools $\left.{ }^{\circledR}\right)$, using TaqMan technology and the primers and probes, as described by Costafreda et al. [36], was used for the analysis of all samples

- $\quad$ Norovirus GI: a commercial $r t$ RT-PCR assay (KNVGI: ceeramTools ${ }^{\circledR}$ ), using TaqMan technology and using the primers and probes, as described by Da Silva et al. [37] and Svraka et al. [38], was used for the analysis of all samples.

- $\quad$ Norovirus GII: a commercial $r t$ RT-PCR assay (KNVGII: ceeramTools ${ }^{\circledR}$ ) using TaqMan technology and the primers and probes, as described by Kageyama et al. [39] and Loisy et al. [40], was used for the analysis of all samples.

- $\quad$ Rotaviruses: a commercial $r t$ RT-PCR assay (KRV: ceeramTools ${ }^{\circledR}$ ) using TaqMan technology used for the analysis of all samples.

- Sapoviruses: the $r t$ RT-PCR assay, using TaqMan technology and the primers and probes as described by Chan et al. [41] was used for the analysis of samples. The molecular amplification and real-time RT-PCR detection was executed using the Transcriptor First Strand cDNA synthesis kit (Roche) in conjunction with the LightCycler ${ }^{\circledR}$ Taqman ${ }^{\circledR}$ master kit (Roche).

- Mengovirus: a commercial $r t$ RT-PCR assay (KMG: ceeramTools ${ }^{\circledR}$ ), using TaqMan technology and the primers and probes, as described by Pintó et al. [42], was used for the detection of Mengovirus in all artificially seeded samples. If the Mengovirus or target were not detected, then RNA/DNA were diluted $1 / 10$ and retested (dilutes out inhibitors).

\section{Results and Discussion}

Table 1 lists the various activities that were observed taking place around the river sites during this study. Many of these activities are considered to be risk factors and they could lead to the contamination of river water, such as agricultural activities, washing laundry, car washing, littering, dumping of animal blood, and domestic sewage disposal $[4,5,43,44]$.

Table 1. Activities seen around the selected river water sites.

\begin{tabular}{cl}
\hline River Sampling Site & \multicolumn{1}{c}{ Description of Observed Activities } \\
\hline Mutale river & Laundry, bathing, car washing, cattle drink from the river \\
\hline Sambandou river & $\begin{array}{l}\text { Laundry, cattle and donkeys drink from the river, animals grazing, people fetch } \\
\text { water for construction purposes and other household activities, animal faecal } \\
\text { matter around the area }\end{array}$ \\
\hline Tshinane river & Laundry, bathing, dumping of chicken feathers and blood \\
\hline Mutshundudi river & Laundry, bathing, littering \\
\hline Madadzhe river & Agricultural activities, domestic sewage disposal, car washing \\
\hline Luvuvhu river (Mhinga site) & Laundry, car washing, swimming, bathing, fishing \\
\hline Luvuvhu river (Tshino site) & Cattle grazing, fishing \\
\hline Nzhelele river & Car washing, people fetch water, swimming, agricultural activities \\
\hline Dzindi river & Agricultural activities \\
\hline
\end{tabular}

\subsection{Assessment of Water Quality Using Physical Parameters and Indicator Bacteria}

Table 2 summarises the physical and the microbial indicator data for the winter and summer seasons. The $\mathrm{pH}$ of water plays an important role for biological activities of microorganisms. In this 
study, the $\mathrm{pH}$ of water samples ranged from 6.79 to 8.19 in the summer and from 7.19 to 8.42 in winter. These were within the South African Water Quality guideline standards of 5.0 to 9.0 [45] for domestic use. Temperature is a key determinant of growth and survival of microbes in water and it plays an important role in their survival $[46,47]$. Microbial growth increases with temperature, and this might increase the problems related to taste, odour, and colour of water $[48,49]$. According to literature, warmer temperatures during summer go along with Salmonella, Campylobacter, or E. coli infections [50,51], and low winter temperatures favours viruses, such as Rotavirus and Noroviruses [52,53]. In this study, the temperature of water samples ranged from $22.9^{\circ} \mathrm{C}$ to $28.3^{\circ} \mathrm{C}$ in the summer and from $16.0^{\circ} \mathrm{C}$ to $20.3^{\circ} \mathrm{C}$ in winter. Several of the river sites had summer temperatures that were higher than the South African recommended water quality guideline standards of $18^{\circ} \mathrm{C}$ to $24^{\circ} \mathrm{C}$ (Table 2).

TDS indicates the degree of salinity in a water sample and no health effects would be associated with water with TDS levels of $0-450 \mathrm{mg} / \mathrm{L} \mathrm{[45].} \mathrm{In} \mathrm{this} \mathrm{study,} \mathrm{the} \mathrm{TDS} \mathrm{of} \mathrm{water} \mathrm{samples} \mathrm{were} \mathrm{well} \mathrm{within}$ the South African water quality guideline standards [45] and ranged from $26.8 \mathrm{mg} / \mathrm{L}$ to $142.1 \mathrm{mg} / \mathrm{L}$ in the summer and from $29.9 \mathrm{mg} / \mathrm{L}$ to $348.5 \mathrm{mg} / \mathrm{L}$ in winter. Electrical conductivity (EC) is a measure of the ability of water to conduct electricity, and this is directly dependent on the concentration of dissolved ions, which establishes a direct relationship between EC and TDS (DWAF, 1996). According to the DWAF [45], the target water quality guideline range for domestic use based on conductivity is $0-70 \mathrm{mS} / \mathrm{m}(0-700 \mu \mathrm{S} / \mathrm{cm})$. The latest updates by SANS 241 [54] has specified the standard limits based on EC to be $<170 \mathrm{mS} / \mathrm{m}(1700 \mu \mathrm{S} / \mathrm{cm})$. In this study, the EC of water samples were well within South African water quality guideline standards [45] and they ranged from $53.3 \mu \mathrm{S} / \mathrm{cm}$ to $285 \mu \mathrm{S} / \mathrm{cm}$ in the summer and from $63.3 \mu \mathrm{S} / \mathrm{cm}$ to $601 \mu \mathrm{S} / \mathrm{cm}$ in winter. Dissolved oxygen (DO) characterizes the freshness of surface water which is directly related to the amount of oxygen dissolved. This is supported by a positive correlation between biological oxygen demand (BOD) and bacterial counts that Borade et al. [55] observed. According to DWAF [45], there are no specific guidelines in place for DO. In this study, the DO of water samples ranged from $2.04 \mathrm{mg} / \mathrm{L}$ to $9.88 \mathrm{mg} / \mathrm{L}$ in the summer and from $9.16 \mathrm{mg} / \mathrm{L}$ to $13.43 \mathrm{mg} / \mathrm{L}$ in winter. Several of the river sites during both seasons had DO readings that were higher than the South African water quality guideline recommended standards [45] of 6.0 to $8.0 \mathrm{mg} / \mathrm{L}$ (Table 3). These counts could have a health effect on humans and aquatic life in the rivers [56].

Total coliforms (TC) and E. coli are known as indicator organisms and the presence of TC provides an indication of other disease-causing organisms in the water source, while the presence of E. coli provides an indication of recent faecal contamination. The number of TC bacteria in drinking water should be less than 10 colonies per $100 \mathrm{~mL}$, while the number of E. coli should be zero per $100 \mathrm{~mL}$ [45] if the water is used for drinking water, according to the South African Guidelines. The TC and E. coli counts in all the sites and in both seasons were far above the South African recommended guideline limits for drinking water (Table 2). The TC counts ranged between 1732 and $2420 \mathrm{MPN} / 100 \mathrm{~mL}$ in both seasons, while the E. coli counts ranged between 57.1 and $1299.7 \mathrm{MPN} / 100 \mathrm{~mL}$ in summer and between 12.2 and $2420 \mathrm{MPN} / 100 \mathrm{~mL}$ in winter. The high counts that were seen for E. coli in these rivers indicated a relatively high level of contamination with faecal human or animal wastes and have also been reported in other studies [4,5,9]; while, the high counts of TC bacteria indicate not only faecal waste, but also the presence of other potentially dangerous bacteria spp. in the water samples. 
Table 2. Physical parameters and indicator bacteria detected in eight rivers in the Limpopo Province.

\begin{tabular}{|c|c|c|c|c|c|c|c|c|c|}
\hline River Site & Season & $\mathrm{pH}$ & $\begin{array}{l}\text { Temp } \\
\left({ }^{\circ} \mathrm{C}\right)\end{array}$ & $\begin{array}{l}\text { TDS } \\
(\mathrm{mg} / \mathrm{L})\end{array}$ & $\begin{array}{l}\text { Cond } \\
(\mu \mathrm{S} / \mathrm{cm})\end{array}$ & $\begin{array}{c}\mathrm{DO} \\
(\mathrm{mg} / \mathrm{L})\end{array}$ & $\begin{array}{l}\text { Total Coliforms } \\
\text { (MPN/100 mL) }\end{array}$ & $\begin{array}{l}\text { E. coli } \\
\text { (MPN/100 mL) }\end{array}$ & $\begin{array}{l}\text { C. perfringes } \\
\text { (CFU/100 mL) }\end{array}$ \\
\hline \multirow{2}{*}{ Mutale river } & Summer & 7.842 & 24.4 & 35.5 & 77 & 9.53 & $>2420$ & 344.8 & 16 \\
\hline & Winter & 8.008 & 17.6 & 29.9 & 63.3 & 10.89 & 1732.9 & 111.2 & 5 \\
\hline \multirow{2}{*}{ Sambandou river } & Summer & 7.703 & 22.9 & 30.6 & 63.1 & 5.19 & $>2420$ & 135.4 & 7 \\
\hline & Winter & 7.489 & 17.8 & 34.3 & 71.4 & 9.62 & $>2420$ & 12.2 & 7 \\
\hline \multirow{2}{*}{ Tshinane river } & Summer & 7.83 & 23.6 & 45.1 & 93.6 & 9.88 & $>2420$ & 365.4 & 9 \\
\hline & Winter & 7.776 & 16.0 & 44.2 & 89.3 & 11.07 & 1732.9 & 143.9 & 0 \\
\hline \multirow{2}{*}{ Mutshundudi river } & Summer & 7.746 & 21.1 & 67.3 & 134.6 & 7.09 & 1986.3 & 62 & 12 \\
\hline & Winter & 7.735 & 16.6 & 46.9 & 94.35 & 11.14 & $>2420$ & 980.4 & 137 \\
\hline \multirow{2}{*}{ Madadzhe river } & Summer & 7.218 & 21.2 & 34.5 & 69 & 2.04 & $>2420$ & 1299.7 & 21 \\
\hline & Winter & 7.186 & 20.0 & 102 & 205.5 & 9.16 & $>2420$ & 2420 & $>500$ \\
\hline \multirow{2}{*}{ Luvuvhu river (Mhinga) } & Summer & 7.358 & 26.8 & 71.3 & 142.6 & 7.01 & $>2420$ & 387.3 & 21 \\
\hline & Winter & 8.101 & 19.2 & 80.5 & 140 & 12.15 & $>2420$ & 488.4 & 7 \\
\hline \multirow{2}{*}{ Luvuvhu river (Mutoti) } & Summer & 8.192 & 24.9 & 64.9 & 130.3 & 6.66 & 1986.3 & 57.1 & 0 \\
\hline & Winter & 8.375 & 19.2 & 77.4 & 134.4 & 12.29 & 980.4 & 29.2 & 0 \\
\hline \multirow{2}{*}{ Luvuvhu river (Tshino) } & Summer & 7.361 & 28.3 & 59.2 & 118.9 & 5.08 & $>2420$ & 209.8 & 9 \\
\hline & Winter & 8.308 & 19.9 & 69.9 & 121.6 & 12.52 & $>2420$ & 235.9 & 0 \\
\hline \multirow{2}{*}{ Nzhelele river } & Summer & 6.975 & 27.2 & 142.1 & 285 & 4.77 & $>2420$ & 461.1 & 21 \\
\hline & Winter & 8.381 & 20.3 & 348.5 & 601 & 11.36 & 1732.9 & 435.2 & 19 \\
\hline \multirow{2}{*}{ Dzindi river } & Summer & 6.791 & 28.8 & 26.8 & 53.3 & 5.13 & $>2420$ & 579.4 & 35 \\
\hline & Winter & 8.421 & 20.0 & 70.3 & 122.2 & 13.43 & 1732.9 & 135.4 & 9 \\
\hline \multirow{2}{*}{\multicolumn{2}{|c|}{$\begin{array}{l}\text { South African Standards [45] } \\
\text { SANS 241-1 [54] }\end{array}$}} & $5.0-9.5$ & $18-24$ & $450-900$ & $400-900$ & $6.0-8.0$ & $0-5$ & 0 & 0 \\
\hline & & $\geq 5.0-\leq 9.5$ & - & $\leq 1200$ & $\leq 170 *$ & - & $<10$ & 0 & - \\
\hline
\end{tabular}

${ }^{*} \mathrm{mS} / \mathrm{m}$. 
Table 3. Pathogenic bacteria, protozoa and virus pathogens isolated in various rivers in the Limpopo province, South Africa.

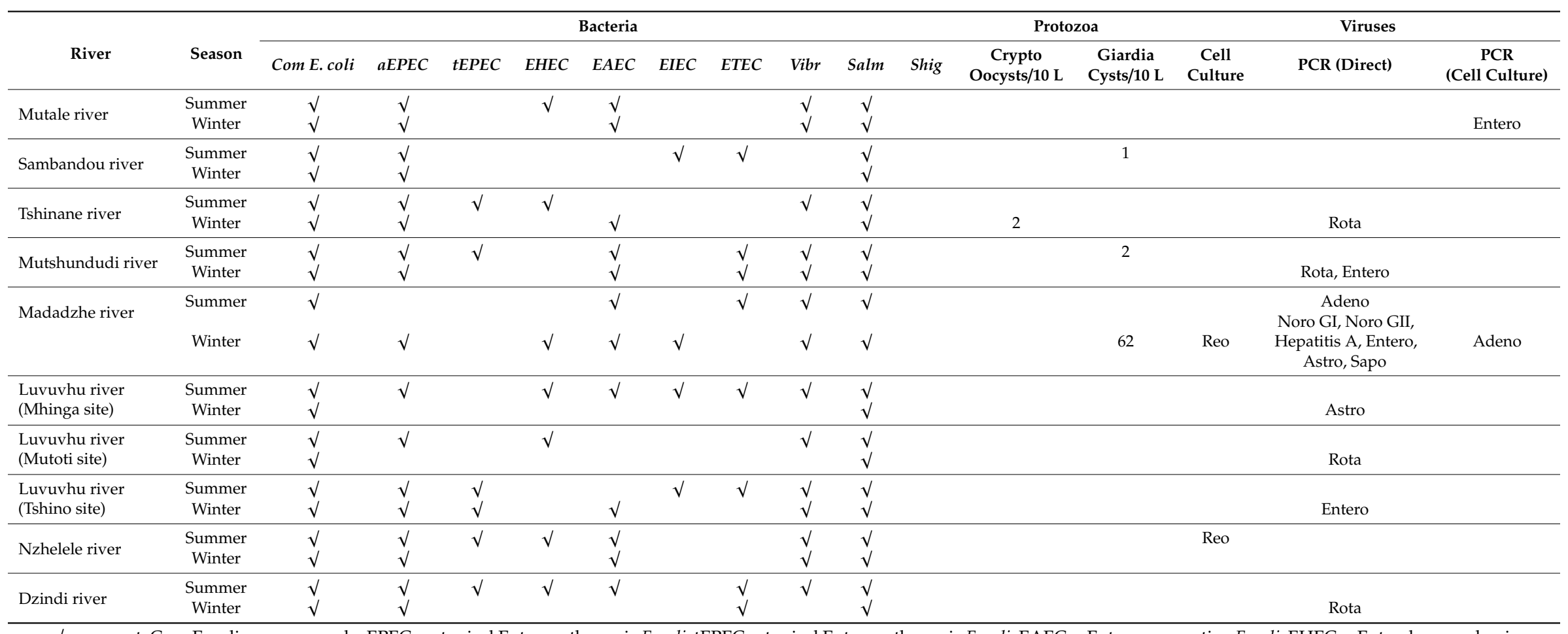

$\sqrt{ }=$ present; Com E. coli = commensal; aEPEC = atypical Enteropathogenic E. coli; tEPEC = typical Enteropathogenic E. coli; EAEC = Enteroaggregative E. coli; EHEC = Enterohaemorrhagic E. coli; EIEC = Enteroinvasive E. coli; ETEC = Enterotoxigenic E. coli; Vibr = Vibrio spp.; Salm = Salmolella spp.; Shig = Shigella spp. 
The identification of bacterial isolates using the API20E test kit showed that some isolates that were isolated from the water sources were Aeromonas-, Serratia-, Proteus-, Plessiomonas-, Enterobacter, Citrobacter-, Edwardsiella-, Yersinia-, and Biber steria spp., which are coliform bacteria that could be harmful to humans and have been known to cause severe global outbreaks [49]. Therefore, the river water is not recommended to be used for drinking or other domestic purposes [45].

The South African water quality guidelines [45] recommends that no C. perfringens should be detected in a $100 \mathrm{~mL}$ water sample. In this study, C. perfringens counts ranged between 0 and $35 \mathrm{cfu} / 100 \mathrm{~mL}$ in summer and between 0 and $>500 \mathrm{cfu} / 100 \mathrm{~mL}$ in winter. The prevalence of $C$. perfringens in water samples can be an indication of intermittent faecal contamination [49].

\subsection{Prevalence of Pathogens}

Table 3 summarises the prevalence of pathogenic bacteria, protozoa, and enteric viruses in the eight rivers during the winter and summer seasons over a one-year survey. Several pathogenic strains of E. coli were detected and identified from the river sites. It must be pointed out that the PCRs were performed on mixed cultures from the Quanti-Tray ${ }^{\circledR} / 2000$ and, as such, conclusions cannot be drawn regarding the presence of a single or multiple pathogenic $E$. coli strains. In recent years, it has been shown that new pathogenic E. coli groups have emerged, such as the diffusely adherent $E$. coli (DAEC), Shiga toxin producing enteroaggregative E. coli, and adherent invasive E. coli [57], and highlights the need for the isolation and study of the pathogenic E. coli strains in these river samples.

The most prevalent strains identified included atypical enteropathogenic E. coli (EPEC), followed by enteroaggregative E. coli (EAEC). EPEC has emerged as an important pathogen in outbreaks of acute diarrhoea in developed [58] and developing countries [59,60] and both EPEC and EAEC infections are dangerous in immunocompromised individuals and children [61-63]. A study by Traore et al. [5] on some of the rivers in the Venda region detected several pathogenic strains of E. coli, such as enteroinvasive E. coli (EIEC), enterotoxigenic E. coli (ETEC), and enteropathogenic E. coli (EPEC), which are strains that are known for causing diarrhoea in children [24] and that was also detected in this study.

Vibrio spp. could cause cholera, which is responsible for high mortality, and is most commonly transmitted via contaminated water. Several communities in the northern parts of South Africa have experienced a large cholera outbreak during 2008/2009, and a total of 721 cases were confirmed. This outbreak was due to human movement, lack of sanitation infrastructures, and contaminated water sources $[64,65]$. In this study, the presence of $V$. cholerae was shown through the detection of the $\operatorname{sodB}$ gene [66]. This gene was detected in $9 / 10(90 \%)$ and in $5 / 10(50 \%)$ of the sources, respectively, during the summer and winter seasons over the study period. Nontoxic Vibrio spp. is widespread in water environments [49] and $V$. cholerae has been isolated from surface water $[67,68]$ with the occurrence of $V$. cholerae in water sources that are linked to faecal pollution [69].

Salmonella spp. has been repeatedly detected in various types of natural waters, such as rivers, lakes, coastal waters, estuarine, as well as contaminated ground water [70-73]. The presence of Salmonella spp. in natural water resources has also been attributed to runoff from fields with animal husbandry and the disposal of untreated sewage [70]. A study by Potgieter et al. [74] on surface water used as drinking water source in the Vhembe District of Limpopo Province in South Africa has shown that the water was positive for Salmonella. Salmonella spp. is widespread, but certain species can cause gastrointestinal disease, septicemia, and enteric fever, and can contaminate water and food [49]. In this study, Salmonella spp. was detected in both seasons from all sites while using the ipaB gene. No Shigella bacteria were identified during this study.

River water has been shown to be subjected to contamination by protozoan parasites, such as Cryptosporidium and Giardia, due to point or non-point pollution sources [75]. According to Robertson et al. [76], Cryptosporidium and Giardia are both associated with sewage and, thus, contamination of water sources by sewage threatens human health due to their low infectivity dose as low as 10 oocysts/cysts $[77,78]$. Reports on parasitic organisms in wastewater are rare in 
South Africa and, yet, Cryptosporidium and Giardia are reported to be the most prevalent parasites in wastewater samples [79]. In this study, Cryptosporidium and Giardia were detected in four of the river sites. Three of the river sites tested positive for the presence of Giardia sists, of which the Madadzhe river site had 62 cysts/100 mL. Only the Tshihane river site tested positive for the presence of Cryptsporidium oocysts.

Generally, human enteric viruses are excreted in high concentrations in the feces of infected people and they have great potential to pollute water sources $[80,81]$. Outbreaks caused by viruses in South Africa have been reported by Taylor et al. [82], Mans et al. [83] and Rinaldi et al. [84].

Similarly, only a few studies have been done and reported on the prevalence of viruses in South African water sources, such as the prevalence of Enteroviruses [27,85-89]; Astrovirus [90,91], Rotaviruses [89,92,93] and Hepatititis A virus [89,90,94].

Enteric viruses are mainly transmitted by faecally-contaminated water or food. Infected individuals excrete enteric viruses in numbers up to $10 / \mathrm{g}$ faeces and compared with most pathogens, the minimal infectious dose is extremely low. It has been reported that a single virus can cause infection [54]. In this study, viruses were detected in all river sites, except the Sambandou river site (Table 3). Direct PCR detection was more sensitive in showing the presence of viral strains in the water samples. Rotavirus, Enterovirus, and Astrovirus were only detected during the winter months supporting the report of Steele and Glass [95] that Rotaviruses and Enteroviruses prefer dry winter months. Van Heerden et al. [96] has shown that Adenoviruses are linked to respiratory and gastrointestinal infections. It is known that viruses have a low infectivity dosage and generally the risk of viral infection depends on several factors, such as specifics of the individual (eg. age and health status) and the characteristics of the virus [89]. However, there are no data regarding the detection of enteric viruses in surface waters in the Vhembe District, except in a study done by Obi et al. [9], which detected somatic phages, a likely indicator of viral contamination of water [97-99]. Hence, little is known regarding the frequency and pattern of viral contamination of drinking water sources in resource poor settings, such as rural areas in the Vhembe District [100]. Human anthropogenic activities, animals, and agricultural activities may have huge impact on the prevalence of viruses in nonprotected water sources [5]. The river water is potentially hazardous to public health if stored at the household in various types of containers and under questionable hygienic conditions and used untreated [7].

\section{Conclusions}

Water samples that were collected from 10 sites in eight rivers in the Limpopo Province were analyzed for faecal contamination as well as human enteric pathogens representing bacterial, protozoan, and viral contamination. The enteric pathogens that were detected from the river water samples analyzed in this study only represented a single time point (either winter or summer season) and, therefore, it is possible that the types of enteric pathogens found could differ if the samples were collected at different periods during the year. Generally, the results indicated the deterioration of water quality in these river catchments, which is used by the rural communities as a source of drinking water during intermittent water supplies to taps or when taps and boreholes run dry or break down. The Madadzhe River was the most contaminated river site (Tables 2 and 3). Agricultural flow and sewage disposal (Table 1) could be the contributing factors in the contamination of this water site [4].

In all cases, the prevalence of enteric bacteria, parasites, and viruses in surface water highlights the importance of assessing the water sources used for domestic purposes for contamination Although this study only reports on a one-year surveillance, there is need for the urgent implementation of improved management strategies of these river catchments by Municipalities in the Limpopo Province for catchment sustainability.

Author Contributions: N.P. and A.T. designed the study protocol and supervised the student; S.K. carried out the field and laboratory work; N.P., S.K., L.S.M., A.T. and T.B. contributed in analysis of data; writing the draft manuscript and revision of manuscript. All authors have read and agreed to the published version of the manuscript. 
Funding: This research was funded by the Water Research Commission (WRC) of South Africa grant number [TT $760 \mathrm{Vol} 1$ 1] and the Research \& Innovation Directorate of the University of Venda [SMNS/16/MBY/07/2904].

Acknowledgments: The authors would like to acknowledge the Rand Water for parasite detection and characterization and Pretoria University for viral detection and characterization.

Conflicts of Interest: The authors declare no conflict of interest.

\section{References}

1. Zamxaka, M.; Pironcheva, G.; Muyima, N. Microbiological and physico-chemical assessment of the quality of domestic water sources in selected rural communities of the Eastern Cape Province, South Africa. Water SA 2004, 30, 333-340. [CrossRef]

2. Lewin, S.; Norman, R.; Nannan, N.; Thomas, E.; Bradshaw, D. Estimating the burden of disease attributable to unsafe water and lack of sanitation and hygiene in South Africa in 2000: Original article. S. Afr. Med. J. 2007, 97, 755-762.

3. Bessong, P.O.; Odiyo, J.O.; Musekene, J.N.; Tessema, A. Spatial distribution of diarrhoea and microbial quality of domestic water during an outbreak of diarrhoea in the Tshikuwi community in Venda, South Africa. J. Health Popul. Nutr. 2009, 27, 652-659. [CrossRef] [PubMed]

4. Gumbo, J.R.; Dzaga, R.A.; Nethengwe, N.S. Impact on water quality of Nandoni Water reservoir downstream of municipal sewage plant in Vhembe District, South Africa. Sustainability 2016, 8, 597. [CrossRef]

5. Traoré, A.N.; Mulaudzi, K.; Chari, G.; Foord, S.H.; Mudau, L.S.; Barnard, T.G.; Potgieter, N. The Impact of Human Activities on Microbial Quality of Rivers in the Vhembe District, South Africa. Int. J. Environ. Res. Public Health 2016, 13, 817. [CrossRef] [PubMed]

6. Sibanda, T.; Okoh, A.I. Real-time PCR quantitative assessment of hepatitis A virus, rotaviruses and enteroviruses in the Tyume River located in the Eastern Cape Province, South Africa. Water SA 2013, 39, 295-304. [CrossRef]

7. Potgieter, N.; Becker, P.J.; Ehlers, M.M. Evaluation of the CDC safe water-storage intervention to improve the microbiological quality of point-of-use drinking water in rural communities in South Africa. Water SA 2009, 35, 505-515. [CrossRef]

8. Peter-Varbanets, M.; Gujer, W.; Pronk, W. Intermittent operation of ultra-low-pressure ultrafiltration for decentralized drinking water treatment. Water Res. 2012, 46, 3272-3282. [CrossRef]

9. Obi, C.L.; Potgieter, N.; Bessong, P.O.; Matsaung, G. Assessment of the microbial quality of river water sources in rural Venda communities in South Africa. Water SA 2002, 28, 287-292. [CrossRef]

10. Palamuleni, L.; Akoth, M. Physico-Chemical and Microbial Analysis of Selected Borehole Water in Mahikeng. S. Afr. Int. J. Environ. Res. Public Health 2015, 12, 8619-8630. [CrossRef]

11. Brick, T.; Primrose, B.; Chandrasekhar, R.; Roy, S.; Muliyil, J.; Kang, G. Water contamination in urban south India: Household storage practices and their implications for water safety and enteric infections. Int. J. Hyg. Environ. Health 2004, 207, 473-480. [CrossRef] [PubMed]

12. Smith, A.; Reacher, M.; Smerdon, W.; Adak, G.K.; Nichols, G.; Chalmers, R.M. Outbreaks of waterborne infectious intestinal disease in England and Wales, 1992-2003. Epidemiol. Infect. 2006, 134, 1141-1149. [CrossRef] [PubMed]

13. Mudau, L.S.; Mukhola, M.S.; Hunter, P.R. Cholera and household treatment why communities do not treat water after a cholera outbreak: A case study in Limpopo Province. S. Arica J. Infect. Dis. 2016, 1, 1-4.

14. Ikeda, T.; Kapwata, T.; Behera, S.K.; Minakawa, N.; Hashizume, M.; Sweijd, N.; Mathee, A.; Wright, C.Y. Climatic factors in relation to diarrhoea hospital admissions in rural Limpopo, South Africa. Atmosphere 2019, 10, 522. [CrossRef]

15. Chandra, R.; Sing, S.; Raj, A. Seasonal bacteriological analysis of Gola river water contaminated with pulp paper mill waste in Uttaranchal, India. Environ. Monit. Assess. 2006, 118, 393-406. [CrossRef]

16. Bisson, J.W.; Cabelli, V.J. Membrane filter enumeration method for Clostridium perfringens. Appl. Environ. Microbiol. 1979, 37, 55-66. [CrossRef]

17. Mueller-Spitz, S.R.; Stewart, L.B.; McLellan, S.L. Reliability of m-CP method for identification of Clostridium perfringens from faecal polluted aquatic environment. J. Appl. Microbiol. 2009, 108, 1994-2002.

18. Environmental Protection Agency (EPA). Information Collection Rule Microbial Laboratory Manual; EPA/600/R-95/178, section XI; Environmental Protection Agency: Washington, DC, USA, 1996. 
19. Bonde, G.J. Bacterial Indicators of Water Pollution. A Study of Quantitative Estimation, 2nd ed.; Teknisk Forlag: Copenhagen, Denmark, 1963.

20. Choopun, N.; Louis, V.; Huq, A.; Colwell, R.R. Simple procedure for rapid identification of Vibrio cholerae from the aquatic environment. Appl. Environ. Microbiol. 2002, 68, 995-998. [CrossRef]

21. Prescott, H. Laboratory Exercises in Microbiology, 5th ed.; McGraw-Hill: New York, NY, USA, 2002; pp. $42-45$.

22. Willey, J.M.; Sherwood, L.M.; Woolverton, C.J. Prescott's Microbiology, 9th ed.; McGraw-Hill: New York, NY, USA, 2014; p. 33.

23. Mieta, S.I.K.; Potgieter, N.; Sobsey, M.D.; Barnard, T.G. Optimisation of methods for the collection and detection of bacterial pathogens from diarrheal human faecal samples using a novel stool collection kit. Water SA 2010, 36, 159-166. [CrossRef]

24. Omar, K.B.; Barnard, T.G. Detection of diarrhoeagenic Escherichia coli in clinical and environmental water sources in South Africa using single-step 11-gene m-PCR. World J. Microbiol. Biotechnol. 2014, 30, 2663-2671. [CrossRef]

25. Environmental Protection Agency (EPA). Method 1623.1 for Cryptosporidium and Giardia in Water by Filtration/IMS//FA; United States Environmental Protection Agency: Washington, DC, USA, 2012.

26. Mans, J.; Netshikweta, R.; Magwalivha, M.; Van Zyl, W.B.; Taylor, M.B. Diverse norovirus genotypes identified in sewage polluted river water in South Africa. Epidemiol. Infect. 2013, 141, 303-313. [CrossRef]

27. Kiulia, N.M.; Netshikweta, R.N.A.; van Zyl, W.B.; Kiraithe, M.M.; Nyachieo, A.; Mwenda, J.M.; Taylor, M.B. The detection of enteric viruses in selected urban and rural river water and sewage in Kenya, with special reference to Rotaviruses. J. Appl. Microbiol. 2010, 109, 818-828. [CrossRef] [PubMed]

28. Minor, P.D. Growth, assay and purification of Picornaviruses. In Virology: A Practical Approach; Mahy, B.W.J., Ed.; IRL Press Ltd.: Oxford, UK, 1985; pp. 25-41.

29. Vilaginès, P.H.; Suarez, A.; Sarrette, B.; Vilaginès, R. Optimisation of the PEG re-concentration procedure for virus detection by cell culture or genomic amplification. Water Sci. Technol. 1997, 35, 455-459. [CrossRef]

30. Alexander, J.J.; Bey, E.M.; Geddes, E.W.; Lecastsas, G. Establishment of a continuous growing cell line from a primary carcinoma of the liver. S. Afr. Med. J. 1976, 50, 2124-2128. [PubMed]

31. Dahling, D.R.; Berg, G.; Berman, D. BMG, a continuous cell line more sensitive than primary rhesus and African green monkey kidney cells for the recovery of viruses from water. Health Lab. Sci. 1974, 11, 275-285. [PubMed]

32. Grabow, W.O.K.; Botma, K.L.; Villiers, J.C.; Clay, C.G.; Erasmus, B. Assessment of cell culture and polymerase chain reaction procedures for the detection of poliovirus in wastewater. Bull. World Health Organ. 1999, 77, 973-978.

33. Vivier, J.C.; Ehlers, M.M.; Grabow, W.O.K. Detection of Enteroviruses in treated drinking water. Water Res. 2004, 38, 2699-2705. [CrossRef]

34. Fuhrman, J.A.; Jiang, X.; Noble, R.T. Rapid detection of Enteroviruses in small volume of natural waters by real-time quantitative reverse transcriptase PCR. Appl. Environ. Microbiol. 2005, 71, 4523-4530. [CrossRef]

35. Heim, A.; Ebnet, C.; Harste, G.; Pring-Akerblom, P. Rapid and quantitative detection of human adenovirus DNA by real-time PCR. J. Med. Virol. 2003, 70, 228-239. [CrossRef]

36. Costafreda, M.I.; Bosch, A.; Pinto, R.M. Development, evaluation and standardisation of a real-time Taqman reverse transcription-PCR assay for the quantification of hepatitis A virus in clinical and shellfish samples. Appl. Environ. Microbiol. 2006, 72, 3846-3855. [CrossRef]

37. Da Silva, A.K.; Le Saux, J.C.; Parnaudeau, S.; Pommepuy, M.; Elimelech, M.; Le Guyader, F.S. Evaluation of removal of noroviruses during wastewater treatment using real-time reverse transcription-PCR: Different behaviours of genogroups I and II. Appl. Environ. Microbiol. 2007, 73, 7891-7897. [CrossRef] [PubMed]

38. Svraka, S.; Duizer, E.; Vennema, H.; de Bruin, E.; Van der Veer, B.; Dorresteijn, B.; Koopmans, M. Etiological role of viruses in outbreaks of acute gastroenteritis in the Netherlands from 1994 through 2005. J. Clin. Microbiol. 2007, 45, 1389-1394. [CrossRef] [PubMed]

39. Kageyama, T.; Koijima, S.; Shinohara, M.; Uchida, K.; Fukushi, S.; Hoshino, F.B.; Takeda, N.; Katayama, K. Broadly reactive and highly sensitive assay for Norwalk-like viruses based on real-time quantitative reverse transcription-PCR. J. Clin. Microbiol. 2003, 41, 1548-1557. [CrossRef]

40. Loisy, F.; Atmar, R.L.; Guillon, P.; Le Cann, P.; Pommepuy, M.; Le Guyader, F.S. Real-time RT-PCR for norovirus screening in shellfish. J. Virol. Methods 2005, 123, 1-7. [CrossRef] [PubMed] 
41. Chan, M.C.W.; Sung, J.J.Y.; Lam, R.K.Y.; Chan, P.K.S.; Lai, R.W.M.; Leung, W.K. Sapovirus detection by quantitative real-time RT-PCR in clinical stool specimens. J. Virol. Methods 2006, 134, 146-153. [CrossRef]

42. Pintó, R.M.; Costafreda, M.I.; Bosch, A. Risk assessment in shellfish-borne outbreaks of hepatitis A. Appl. Environ. Microbiol. 2009, 75, 7350-7355. [CrossRef]

43. Genthe, B.; Le Roux, W.J.; Schachtschneider, K.; Oberholster, P.J.; Aneck-Hahn, N.J.; Chamier, J. Health risk implications from simultaneous exposure to multiple environmental contaminants. Ecotoxicol. Environ. Saf. 2013, 93, 171-179. [CrossRef]

44. John, J.; Wright, C.Y.; Oosthuizen, M.A.; Steyn, M.; Genthe, B.; le Roux, W.; Albers, P.; Oberholster, P.A.; Pauw, C. Environmental health outcomes and exposure risks among at-risk communities living in the Upper Olifants River Catchment, South Africa. Int. J. Environ. Health Research 2014, 24, 195-214. [CrossRef]

45. Department of Water Affairs Forestry (DWAF). South African Water Quality Guidelines, 2nd Ed. ed; Volume 2: Domestic Use; The Government Printer: Pretoria, South Africa, 1996.

46. United Nations Children's Fund (UNICEF). UNICEF Handbook on Water Quality, 3 UN Plaza; UNICEF: New York, NY, USA, 2008; p. 10017.

47. Bishankha, S.; Bhatta, D.R.; Josh, D.R.; Joshi, T.P. Assessment of microbial quality of chlorinated drinking tap water and susceptibility of Gram-negative bacterial isolates towards chlorine. Khathmandu Univ. J. Sci. Eng. Technol. 2013, 9, 222-229. [CrossRef]

48. Krauss, S.; Griebler, C. Pathogenic Microorganisms and Viruses in Groundwater; Acatech Materialien: Munchen, Germany, 2011; pp. 1-66, ISSN 2191-8481, ISBN 978-3-942044-22-6.

49. World Health Organization (WHO). Guidelines for Drinking-Water Quality, 4th ed.; World Health Organization: Geneva, Switzerland, 2011.

50. Kovats, R.S.; Edwards, S.J.; Hajat, S.; Armstrong, B.G.; Ebi, K.L.; Menne, B. The effect of temperature on food poisoning: A time-series analysis of salmonellosis in ten European countries. Epidemiol. Infect. 2004, 132, 443-453. [CrossRef]

51. Fleury, M.; Charron, D.F.; Holt, J.D.; Allen, O.B.; Maarouf, A.R. A time series analysis of the relationship of ambient temperature and common bacterial enteric infections in two Canadian provinces. Int. J. Biometeorol. 2006, 50, 385-391. [CrossRef] [PubMed]

52. Levy, K.; Hubbard, A.E.; Eisenberg, J.N. Seasonality of Rotavirus disease in the tropics: A systematic review and meta-analysis. Int. J. Epidemiol. 2009, 38, 1487-1496. [CrossRef] [PubMed]

53. Keller, R.; Tetro, J.A.; Springthorpe, V.S.; Sattar, S.A. The influence of temperature on Norovirus inactivation by monochloramine in Potable Waters: Testing with murine norovirus as a surrogate for human norovirus. Food Environ. Virol. 2010, 2, 97-100. [CrossRef]

54. SANS 241-1: (2015). South African National Standards (SANS) Ed 2 for Drinking Water. Available online: http://www.sabs.co.za (accessed on 3 October 2016).

55. Borade, S.; Dhawde, R.; Maloo, A.; Gajbhiye, S.N.; Ram, A.; Dastager, S.G. Assessment of enteric bacterial indicators and correlation with physic-chemical parameters in Veraval coast, India. Indian J. Geo Mar. Sci. 2015, 44, 521-525.

56. Rao, P.V. Textbook of Environmental Engineering; Eastern Economy, Ed.; Prentice-Hall of India Private Limited: New Delhi, India, 2005; Chapter 3; p. 280.

57. Fratamico, P.; Liu, Y.; Summers, C. Pathogenic Esherichia Coli: Evolution, Omics, Detection and Control; Caister Academic Press: Norfolk, UK, 2018.

58. Huang, D.B.; Nataro, J.P.; DuPont, H.L.; Kamat, P.P.; Mhatre, A.D.; Okhuysen, P.C.; Chiang, T. Enteroaggregative Escherichia coli is a cause of acute diarrheal illness: A meta-analysis. Clin. Infect. Dis. 2006, 43, 556-563. [CrossRef] [PubMed]

59. Kermani, N.A.; Jafari, F.; Mojarad, H.N.; Hoseinkhan, N.; Zali, R. Prevalence and associated factors of persistent diarrhoea in Iranian children admitted to a paediatric hospital. East. Mediterr. Health J. 2010, 16, 831-836. [CrossRef]

60. Meng, C.Y.; Smith, B.L.; Bodhidatta, L.; Richard, S.A.; Vansith, K.; Thy, B.; Srijan, A.; Serichantalergs, O.; Mason, C.J. Etiology of diarrhea in young children and patterns of antibiotic resistance in Cambodia. Pediatr. Infect. Dis. J. 2011, 30, 331-335. [CrossRef]

61. Okeke, I.N.; Nataro, J.P. Enteroaggregative Escherichia coli. Lancet Infect. Dis. 2001, 1, 304-313. [CrossRef]

62. Chen, D.H.; Frankel, G. Enteropathogenic Escherichia coli: Unravelling pathogenesis. FEMS Microbiol. Rev. 2005, 29, 83-98. [CrossRef] 
63. Samie, A.; Obi, C.L.; Dillingham, R.; Pinkerton, R.C.; Guerrant, R.L. Enteroaggregative Escherichia coli in Venda, South Africa: Distribution of virulence-related genes by multiplex polymerase chain reaction in stool samples of human immunodeficiency virus (HIV)-positive and HIV-negative individuals and primary school children. Am. J. Trop. Med. Hyg. 2007, 77, 142-150.

64. National Institute of Communicable Diseases (NICD) (cited 2012). 2009. 8 (4). Available online: http: //www.nicd.ac.za/assets/files/NICDCommApr09Vol08_04.pdf (accessed on 10 August 2017).

65. Ismail, H.; Smith, A.M.; Tau, N.P.; Sooka, A. Cholera outbreak in South Africa, 2008-2009 laboratory analysis Vibrio cholera O1 strains. S. Afr. J. Infect. Dis. 2013, 208, 39-45. [CrossRef] [PubMed]

66. Ntema, V.M.; Potgieter, N.; Barnard, T.G. Detection of Vibrio cholerae and Vibrio parahaemolyticus by molecular and culture-based methods from source water to household container-stored water at the point-of-use in South African rural communities. Water Sci. Technol. 2010, 61, 3091-3101. [CrossRef]

67. Percival, S.L.; Chalmers, R.M.; Embrey, M.; Hunter, P.R.; Sellwood, J.; Wyn-Jones, P. Microbiology of Waterborne Diseases; Elsevier Academic Press: San Diego, CA, USA, 2004.

68. Fraga, S.G.; Pichel, M.; Costagliola, M.; Cecilia, M.; Jurquiza, V.; Peressutti, S.; Caffer, M.I.; Aulet, O.; Hozbor, C.; Tracanna, B.C.; et al. Environment and virulence factors of Vibrio cholerae strains isolated in Argentina. J. Appl. Microbiol. 2007, 103, 2448-2456. [CrossRef] [PubMed]

69. Cox, P.; Griffith, M.; Angles, M.; Deere, D.; Ferguson, C. Concentrations of pathogens and indicators in animal faeces in the Sydney watershed. Appl. Environ. Microbiol. 2005, 71, 5929-5934. [CrossRef] [PubMed]

70. Moganedi, K.L.M.; Goyvaerts, E.M.A.; Venter, S.N.; Sibara, M.M. Optimization of PCR-invA primers for the detection of Salmonella in drinking and surface waters following a pre-cultivation step. Water SA 2007, 33, 195-202.

71. Haley, B.J.; Cole, D.J.; Lipp, E.K. Distribution, diversity and seasonality of waterborne Salmonella in a rural watershed. Appl. Environ. Microbiol. 2009, 75, 1248-1255. [CrossRef]

72. Wilkes, G.; Edge, T.; Gannon, V.; Jokinen, C.; Lyautey, E.; Medeiros, D. Seasonal relationships among indicator bacteria, pathogenic bacteria, Cryptosporidium oocysts, Giardia cysts, and hydrological indices for surface waters within an agricultural landscape. Water Res. 2009, 43, 2209-2223. [CrossRef]

73. Levantesi, C.; Bonadonna, L.; Briancesco, R.; Grohmann, E.; Toze, S.; Tandoi, V. Salmonella in surface and drinking water: Occurrence and water-mediated transmission. FRIN 2012, 45, 587-602. [CrossRef]

74. Potgieter, N.; Obi, C.L.; Bessong, P.O.; Igumbor, E.O.; Samie, A.; Nengobela, R. Bacterial contamination of Vhuswa-a local weaning food and stored drinking-water in impoverished households in the Venda region of South Africa. J. Health Popul. Nutr. 2005, 23, 150-155.

75. Dreelin, E.A.; Ives, R.L.; Molloy, S.; Rose, J.B. Cryptosporidium and Giardia in surface water: A case study from Michigan, USA to inform management of rural water systems. Int. J. Environ. Res. Public Health 2014, 11, 10480-10503. [CrossRef]

76. Robertson, L.J.; Forberg, T.; Hermansen, L.; Gjerde, B.K.; Alvsvag, J.O.; Langeland, N. Cryptosporidium parvum infections in Bergen, Norway, during an extensive outbreak of waterborne giardiasis in autumn and winter 2004. Appl. Environ. Microbiol. 2006, 72, 2218-2220. [CrossRef] [PubMed]

77. Dallingham, R.A.; Lima, A.A.; Guerrant, R.L. Cryptosporidiosis: Epidemiology and impact. Microbes Infect. 2002, 4, 1059-1066. [CrossRef]

78. Jacek, S.; Krzysztof, S.; Jolanta, Z.; Jacek, K.; Tomasz, C.; Jacek, D. Occurrence of Cryptosporidium oocysts and Giardia cysts in effluent from sewage treatment plant from eastern Poland. Ann Agric Environ Med. 2013, 20,57-62.

79. Samie, A.; Ntekele, P. Genotypic detection and evaluation of the removal efficiency of Giardia duodenalis at municipal wastewater treatment plants in Northern South Africa. Trop. Biomed. 2014, 31, 122-133. [PubMed]

80. Fong, T.T.; Lipp, E.K. Enteric viruses of human and animals in aquatic environments: Heath risks, detection and potential water quality assessment tools. Appl. Environ. Microbiol. 2005, 69, 357-371. [CrossRef] [PubMed]

81. Bosch, A.; Guix, S.; Sano, D.; Pinto, R.M. New tools for the study and direct surveillance of viral pathogens in water. Curr. Opin. Biotechnol. 2008, 19, 1-7. [CrossRef]

82. Taylor, M.B.; Schildhauer, C.I.; Parker, S.; Grabow, W.O.K.; Xi, J.; Estes, M.K. Two successive outbreaks of SRSV-associated gastroenteritis in South Africa. J. Med Virol. 1993, 41, 18-23. [CrossRef]

83. Mans, J.; de Villiers, J.C.; du Plessis, N.M.; Avenant, T.; Taylor, M.B. Emerging norovirus GII.4 2008 variant detected in hospitalised paediatric patients in South Africa. J. Clin. Virol. 2010, 49, 258-264. [CrossRef] 
84. Rinaldi, M.; Brierley, E.; Bekker, A. Donor breastmilk saved infant lives during an outbreak of Rotavirus in South Africa. Breastfeed. Med. 2009, 4, 133-134. [CrossRef]

85. Grabow, W.O.K.; Taylor, M.B.; Wolfaardt, M. Research on Human Viruses in Diffuse Effluents and Related Water Environments; Water Research Commission: Pretoria, South Africa, 1996; pp. 1-25.

86. Vivier, J.C.; Clay, C.G.; Grabow, W.O.K. Detection and rapid differentiation of human Enteroviruses in water sources by restriction enzyme analysis. Water Sci. Technol. 2001, 4, 209-212. [CrossRef]

87. Ehlers, M.M.; Grabow, W.O.K.; Pavlov, D.N. Detection of Enteroviruses in untreated and treated drinking water supplies in South Africa. Water Res. 2005, 39, 2253-2258. [CrossRef] [PubMed]

88. Pavlov, D.N. Poliovirus vaccine strains in sewage and river water in South Africa. Can. J. Microbiol. 2006, 52, 717-723. [CrossRef] [PubMed]

89. Chigor, V.N.; Okoh, A.I. Quantitave RT-PCR detection of Hepatitis A virus, Rotaviruses and Enteroviruses in the Buffalo river and source water dams in the Eastern Cape Province of South Africa. Int. J. Environ. Public Health 2012, 9, 4017-4132. [CrossRef] [PubMed]

90. Taylor, M.B.; Cox, N.; Very, M.A.; Grabow, W.O.K. The occurrence of hepatitis A and astroviruses in selected river and dam waters in South Africa. Water Res. 2001, 35, 2653-2660. [CrossRef]

91. Nadan, S.; Walter, J.E.; Grabow, W.O.K.; Mitchell, D.K.; Taylor, M.B. Molecular characterization of astroviruses by reverse transcriptase PCR and sequence analysis: Comparison of clinical and environmental isolates from South Africa. Appl. Environ. Microbiol. 2003, 69, 747-753. [CrossRef]

92. Genthe, B.; Idema, G.K.; Kfir, R.; Grabow, W.O.K. Detection of Rotavirus in South African waters: A comparison of a cytoimmunolabelling technique with commercially available immunoassays. Water Sci. Technol. 1991, 24, 241-244. [CrossRef]

93. Van Zyl, W.B.; Williams, P.J.; Grabow, W.O.K.; Taylor, M.B. Application of a molecular method for the detection of group A Rotaviruses in raw and treated water. Water Sci. Technol. 2004, 50, 223-228. [CrossRef]

94. Venter, J.M.E.; van Heerden, J.; Vivier, J.C.; Grabow, W.O.K.; Taylor, M.B. Hepatitis A virus in surface water in South Africa: What are the risks? J. Water Health 2007, 5, 229-240. [CrossRef]

95. Steele, A.D.; Glass, R. Rotavirus in South Africa: From discovery to vaccine introduction. S. Afr. J. Epidemiol. Infect. 2011, 26, 184-190. [CrossRef]

96. Van Heerden, J.; Ehlers, M.M.; Vivier, J.C.; Grabow, W.O.K. Risk assessment of adenoviruses detected in treated drinking water and recreational water. J. Appl. Microbiol. 2005, 99, 926-933. [CrossRef]

97. Grabow, W.O.K. Bacteriophages: Update on application as models for viruses in water. Water SA 2001, 27, 251-268. [CrossRef]

98. Hot, D.; Legeay, O.; Jacques, J.; Gantzer, C.; Caudrelier, Y.; Guyard, K.; Lange, M.; Andreoletti, L. Detection of somatic phages, infectious enteroviruses and enterovirus genomes as indicators of human enteric viral pollution in surface water. Water Res. 2003, 37, 4703-4710. [CrossRef]

99. Yousefi, Z.; Zazouli, M.A. Evaluation of Bacteriophages Methods for Detection and Isolation of Viruses from Surface Water. World Appl. Sci. J. 2008, 3, 317-322.

100. Verheyen, J.; Timmen-Wego, M.; Laudien, R.; Boussaad, I.; Sen, S.; Koc, A.; Uesbeck, A.; Mazou, F.; Pfister, H. Detection of adenoviruses and rotaviruses in drinking water sources used in rural areas of Benin, West Africa. Appl. Environ. Microbiol. 2009, 75, 2798-2801. [CrossRef] [PubMed]

(C) 2020 by the authors. Licensee MDPI, Basel, Switzerland. This article is an open access article distributed under the terms and conditions of the Creative Commons Attribution (CC BY) license (http://creativecommons.org/licenses/by/4.0/). 